\title{
Outsourced
}

\section{Equal opportunities?}

\section{Shelly Li}

The sign in the window says: "Offering Jobs to Non-Humans Only."

Oh my God, I think as I trudge along the street, walking and walking to find an employer that will hire a human. It's been three months since the big outsourcing plan was put in place at Microsoft, three months since I'd even seen the inside of a corporate building.

I let out a deep breath, watch the cold smoke seep from my lips and spread out into the Chicago air. What if I never find a job again?

"Hey, watch it!" a voice bleeds into my ear.

I blink to clear the haze out of my eyes and notice that I've run into someone. "Sorry," I say to the alien - I'm not sure what planet he's from - and move back from the inside of his coat, taking my hands off his bluecoloured chest. "I didn't..."

I stop all of a sudden and look down at the tips of my fingers. "Paint...?"

It takes a few seconds for the meaning of this to sink in for me, but when it finally does, I feel the tightening pain in my chest disappear. "Oh my God," I say, looking up at Mr Blue Paint. "You're ... you're a human ... aren't you?"

A terrified scowl drops over his face like a curtain, and he pushes past me and hurries away.

I turn around and watch him as he moves through the people around him, amazed. How can this be? I wonder. Has no one caught him yet?

I don't know the answers to these questions, but what I do know is that if I don't give this man's idea a try, I will not be able to feed my family for much longer.

The interviewer is half-human, half-alien, but with a black overcoat covering her body, the only thing that differentiates her from a full human are the golden spots cast across her forehead.

"So," she says, smiling at me with a row of perfect teeth. "Tell me, Mr Alimano, what is your family history?"

"Well, I was born here in Chicago. My mother emigrated to Earth from Sennia when she was just a few centuries old. When my father came to Earth on business from Polum a couple of millennia later, he and my mother were wed. They gave birth to me a few years later."

The interviewer nodded and pointed to my orange-red hands. "I can see that your mother has given you flexible Sennian

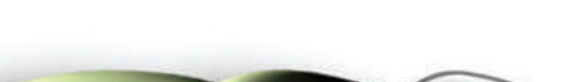

co-workers, and work hard, I am sure that I will stay employed.

Slowly, winter turns to spring, then fades into summer. Summer rolls into autumn, and before I know it, winter is here again. But now my family is living with a roof over their heads and food in their stomachs - perhaps I will even buy Christmas gifts for Nicky and Joel this year, or maybe take a little vacation.

"Hey," my boss walks up and says to me. He once told me that he was from Lotruus, the desert planet, which is why his skin is so green and tough. "Have you typed up the shipment schedule for Sector Seven yet?"

"Yes." I reach over and grab the schedule from the printer, but my arm does not extend far enough. My boss chuckles. "Don't worry," he says, and reaches over me. "I'll grab it."

But his elbow rubs up against my face as he pulls back, and the tingly texture of his skin is too much for me to handle. I sneeze.

For a moment, my boss says nothing, merely stares at me with those piercing eyes of his. Then he glances down at his arm.

I don't understand why he is acting this way until I look down and see the blood mixed in with the snot on his arm.

"This is the blood of a human," my boss fingers," she says. "Those will be perfect for typing. What's your speed?”

My heart freezes then, for I do not know the normal typing speed of an alien. "Nine hundred words a minute," I decide to say after a little pause.

"Hmm. That sounds a little low for a Sennian, but..." She shrugs and writes "900" down on the notepad in front of her. "You are only $50 \%$ of your mother. It's probably reasonable."

She looks up at me, her black eyes piercing into mine, drowning me in a dark abyss. "Mr Alimano," she says. "You're hired. Can you start tomorrow?"

The job is not as hard as I thought it would be. As long as I keep under the radar, socialize at a minimum with my says to me. "Isn't it?"

I keep quiet, and we lapse into silence yet again.

Shivers are rolling through my body, but I can do nothing to stop them. I can hear my heart pounding, louder and louder, almost threatening to burst out of my chest when finally, my boss leans in and whispers to me: "You fix this ... ailment of yours, okay? This encounter of ours did not happen."

I nod, not even daring to breathe.

"Merry Christmas," he says, and walks away.

Shelly Li is now 16 and the proud owner of a driver's licence. Beware. However, when she is not cruising around in her car, she can be found at www.shelly-li.com. 